\title{
The Importance of The Improvement And Convergence of Ias/Ifrs to the National Accounting System of Uzbekistan
}

\author{
S Ergasheva Shakhlo Turgunovna, Kucharov Abror Sabirjanovich, \\ Shermatov Behzod Xalimkul o'g'li.
}

\section{Abstract:}

The relevance of research:

- Economic integration

- Comparability and uniformity of financial statements

- Attraction of prospective overseas investors.

-The requirements of global financial markets and stock exchanges.

- Reduced costs of studying local standards.

Research Objectives:

- Work to improve our accounting systems to accelerate the development of our country with the help of capital of foreign investors.

- Development of our domestic accounting principles based on transnational financial reporting principles and identification of problems associated with this.

\section{INTRODUCTION}

Nowadays, the world is changing very quickly and so is Accounting Practices. As free movement of capital and other resources is very important for the economic and political integration of the countries, harmonization and convergence of accounting and financial reporting can be considered as an integral part of this development. In addition, financial information of different firms around the world, which can be hardly achieved by different accounting and financial reporting practices can be easily compared by shareholders and other stakeholders. The foundation of a more apparent and proficient capital marketplace that will help a lower cost of capital. That is why the harmonization of international accounting standards and the national accounting system has already become an issue, need and problem in Uzbekistan.

When market economy is adopted instead of planned, there occurred the need for infrastructure related to the development of this system, and it is gradually improving after gaining independence.

The progress and issues in the sphere of accounting also can be seen in the market economy. The need of conducting all organizations' accounting based on uniform standards is increasing around the world day by day. This is one of the main ways for attracting the large-scale flow of capital and

Revised Manuscript Received on July 05, 2019.

Ergasheva Shakhlo Turgunovna, Phd of Tashkent State University of Economics, Uzbekistan.

Kucharov Abror Sabirjanovich, Phd of Tashkent State University of Economics, Uzbekistan.

Shermatov Behzod Xalimkul o'g'li, The $2^{\text {nd }}$ year Master degree student of Tashkent State University of Economics, Uzbekistan. maximizing profits..

\section{RESEARCH RESULTS}

Now let's look at the various triggers in turn in order to better understand the real need and problem of bringing international accounting standards into the national accounting system.

Firstly, large foreign investors who have large capital are trying to increase their capital and want to invest in a safe business. Then they begin the search for profitable organizations that have enough property and a best background of doing business. Having found their number, potential investors check and compare their financial results and try to choose the best. Financial data and indicators in the reports allow comparison only if they are prepared in the same way. This is only possible with financial statements prepared according to the international financial reporting standards.

Secondly, it will reduce the cost of studying local standards if financial statements are prepared in accordance with international financial reporting standards. Not only investors, but everyone does not like to spend extra money.

Thirdly, the financial statements of companies must be prepared according to the international financial reporting standards in order to have access to the international financial market and sell their securities there.

Fourth, the transition to international accounting standards or the unification of internal accounting standards encourages foreign investors to start their own business in our country.

Based on the foregoing, we can say that the preparation of financial statements in accordance with international financial reporting standards really helps to attract investor capital.

Coherence across accounting processes in the world and the spread of IFRS rules around the world allow the company, based on IFRS, and all its interested parties to feel confidence in the future prosperity of the company. The role of transparent standards is to increase the accuracy of forecasts, financial and technical support, and market liquidity, as well as to reduce private information owned by the owners of the company and reflecting the value of shares. In addition, this process increases investment and thrives on securities markets.

Our country must constantly support the harmonization process, improving internal coordination in it. The need for harmonization is understandable and beneficial for countries as a whole thanks to the obligations and efforts of regulators, standards 
developers, financiers, the business community, the public and the accounting profession.

\section{CONCLUSIONS}

We made key recommendations in four specific areas:

Organizational framework. With regard to the regulatory framework of Uzbekistan, the following changes should be made:

- Outline norms for differentiating between subjects of attention, small-sized and medium-sized firms and microorganisms to adapt proportional financial reporting requirements that are relevant to market needs and their own information needs.

- Enhancing the audit profession oversight system and create a strong program for audit quality assurance.

Open accessibility of financial statements. Methods to develop compliance with the financial reporting requirements of a company include:

- Preparing financial statements according to the requirements of NAS 1 and submitting all notes to the financial statements to their particular regulatory authority. A regulatory agency must disclose these financial statements and make them publicly available on their websites as legal requirement. At present, financial statements those are disclosed by the companies are simply an income statement and a consolidated balance sheet with the attachment of an audit report on full financial statements.

- In the longer period, a register should be established by the Ministry of Finance which will include centrally filed financial statements of all the companies those will be available for all.

- Continuous cogency and, where applicable, replenishment of audit licenses and certificates for audit firms and individuals should be influenced by the presentation of proof of obedience with related authorized requirements, for example, ongoing specialized improvement, compensation cover, etc. Every five years auditors must take their qualification exams due to the existing requirement of the Ministry of Finance- it seems troublesome and it should be reviewed.

- Moreover, the Ministry of Finance should study the likelihood of changing the appropriate legislation for licensing or approval by the Ministry of Finance, first of all, after meeting certain criteria for professional audit and accounting associations that want to be created in Uzbekistan. In addition, auditors and audit firms must attend recognized associations. This will be the creation of a more reliable and effective audit quality control system.

Official capacity construction. All regulatory bodies and other organizations with financial reporting accountabilities are facing increasing challenges as the moving business atmosphere forms the need for an up-to-date accounting and auditing infrastructure. For example, according to the information displayed, increased volume is required, information that the disclosure requirements listed in NAS 1 are not respected and non-equalization of these disclosures does not always result in a revised audit opinion, even if only a careful attitude is not an urgent need for institutional strengthening in accounting reform. This shows the necessity to toughen the capability of both auditors and the audit quality controller function. Consequently, the following is suggested:

- Supervisory body accept support, containing from worldwide mutual associations, for building their capability in terms of scope, skillfulness level and training of their workforce.

- The similar support should be received by qualified organizations of accountants and auditors in order to increase their ability to better control their participants, particularly in the region of audit quality control and principles.

High-end education and training. Despite the fact that the teaching system appears to provide an adequate number of future professionals, it is necessary to toughen the auditing and accounting capacity of education at universities and ensure connection between institution of higher education study programs and up to professional training, as well as further expansion of existing training programs. programs. The proper understanding and presentation of international standards, and accounting and auditing requirements require a concrete foundation for the teaching and training of financial report makers, auditors and regulatory bodies. To do this, it is recommended that you follow these steps:

- Huge potential is required from existing providers of accounting teachers and trainers to meet the growing requirements of the economy of Uzbekistan. This gradually requires the introduction of new programs to replace the skills of school and university teachers in day-to-day accounting and assessment, which can then be transferred to their students. Alternatively, an accounting teacher in Uzbekistan will teach at another regional university and / or teachers from other countries of the former Soviet Union who have made the necessary changes to university syllabus will be attracted.

- Accounting study program should be comprehensively reviewed to include the NAS, IFRS and accounting principles and theory that underlies the NAS and IFRS at the same time. An analogous attention should be given to the audit theory and principles, fundamental to the ISA and NSA. To the institutions that try to find and generate superior educational programs by means of their own resources, support should be provided.

- Priority should be given to better integration of specialized qualifications and certifying requirements and programs of institution of higher educations, such as the harmonization of university courses and CAP / CIPA, by granting exemptions to university graduates to certain CAP / CIPA exam requirements. Professionals and training providers should also coordinate their CPD training courses.

The above recommendations require a universal multidisciplinary tactic and should be executed progressively after the report' publication. Their execution will require collaboration with a varied kind of interested parties, containing the government, regulatory authorities and the accounting profession, and should be maintained by a senior government figure with strong governmental maintenance. Furthermore, the contribution of peer countries can provide our country - the Republic of Uzbekistan with unique information on how similar problems were solved in similar countries. 
In our country, a working body should be created, consisting of representatives of various groups of interested parties, which will recommend officials and regulatory bodies on how to best execute the recommendations. The strategy should contain a wide-ranging financial plan indicating the assets needed for successful execution. The development partners, stakeholders and government should work together to deliver these resources to accomplish the collective objective of upgrading the quality and accessibility of financial information in our country.

\section{BIBLIOGRAPHY}

I. The laws of the Republic of Uzbekistan

1. Law of the Republic of Uzbekistan "On Accounting" of April 13, 2016 (with subsequent additions and changes).

II. The decrees and orders of the Presidents of the Republic of Uzbekistan

2. Decree of President Islam Karimov of Uzbekistan "On measures on introduction of modern methods of corporate management in joint stock companies" on 24 April 2015.

3. The decision of the President of the Republic of Uzbekistan "On priority directions of further reforming and increasing sustainability of financial-banking system of the republic in 2011-2015 and achieving high international rating indicators." "Collection of Laws of the Republic of Uzbekistan 2010."

III. Resolution of the Cabinet of Ministers of the Republic of Uzbekistan and the legal documents of the ministries

4. National Accounting Standards of the Republic of Uzbekistan. Published in the publishing and information center of the National Association of Accountants and Auditors. -T.:2012.

5. Law of the Republic of Uzbekistan "On Joint-Stock Companies and Protection of Shareholder Rights" of April 26, 1996 (with subsequent amendments and changes).

IV. Textbooks and journals

6. Ball, R., Robin, A., and Wu, J. (2003). Incentives versus standards: properties of accounting income in four East Asian countries and implications for the acceptance of IAS. Journal of Accounting and Economics, 36, 235-270.

7. Brown, P. (2011). "International Financial Reporting Standards: How real are the benefits?" Accounting and Business Research, 41(3), 269-285 p.

8. Choi, F., Frost C., Gary, K. (2002). International Accounting. $4^{\text {th }}$ edition. New Jersey: Prentice Hall, 243-296.

9. DeFond, M., Hu, X., Hung, M., and Li, S. (2011). The impact of mandatory IFRS adoption on foreign mutual fund ownership: The role of comparability. Journal of Accounting and Economics, 51(3), 242-256.

10. Deloitte \& Touche. (2003). IFRS: Of Growing Importance for US Companies. Retrieved on December 1, 2008.

11. International Business \& Economics Research Journal (2010). IFRS Adoption in the EU, Accounting Harmonization And Markets Efficiency: A Review by Gabriele Guggiola, University of Insubria, Varese, Italy Vol. 9, No. 12.

12. Jermakowicz, E. (2004). Effects of Adoption of International Financial Reporting Standards in Belgium: The Evidence from BEL-20 Companies. International Business Research, pp. 198-199.

13. McLeay, S., Neal, D., and Tollington, T., (1999). International Standardization and Harmonization: A New Measurement Technique. Journal of International Financial Management and Accounting, Vol. 10, No. 1, pp. 42-70.

14. Narayan, F.\& Reid, B.(2000). Financial Management and Governance Issues in the Republic of Uzbekistan. Asian Development Bank. Retrieved on January 2, 2009.

15. REPORT ON THE OBSERVANCE OF STANDARDS AND CODES (ROSC), The Republic of Uzbekistan, ACCOUNTING AND AUDITING, December 2008, made by team from World Bank, 38-76 p.

16. Samir, M. S. (2003). Harmonization of Accounting Standards. Chartered Accountant, ICAI.

17. Shima, K. M., \& Gordon, E. A. (2011). IFRS and the regulatory environment: The case of U.S. investor allocation choice. Journal of Accounting and Public Policy, 30(5), 481-500.

18. Turner, L. (2001). Disclosure and Accounting in a Global Market: Looking to the Future. 35-56 $p$.
19. Seidakhmetov LD International standardization and harmonization of accounting and reporting. A., 2006.

\section{Websites}

- http://www.icar.ru - International Center of Accounting Reforms (ICAR)

- http://www.gaap.ru - The information center of theory and practice of financial accounting

- http://www.ifrs.org/Pages/default.aspx - International Accounting Standards Board and IFRS Foundation

- http://www.iasc.org.uk - International Accounting Standards Committee (IASC)

- http://www.fasb.org - Federal Accounting Standard Board USA (FASB)

- http://www.ifac.org/ - International Federation of Accountants (IFAC)

- http://www.accaglobal.com/home/ - Association of Chartered Certified Accountants (ACCA)

- http://www.iosco.org/about/ - The International Organization of Securities Commissions

- http://www.gaap.ru/biblio/gaapias/strategi/ - Developing a strategy to support Russian enterprises in their transition to IFRS

- http://www.lex.uz/ - NATIONAL DATABASE OF LEGISLATION UZBEKISTAN (LexUz) 